\title{
Mobility Justice and the Return of Tourism after the Pandemic
}

Justice mobilitaire et retour du tourisme après la pandémie

\section{Mimi Sheller}

\section{(2) OpenEdition}

\section{Journals}

Electronic version

URL: https://journals.openedition.org/tourisme/3463

DOI: $10.4000 /$ tourisme.3463

ISSN: 2492-7503

\section{Publisher}

Association Mondes du tourisme

\section{Electronic reference}

Mimi Sheller, "Mobility Justice and the Return of Tourism after the Pandemic", Mondes du Tourisme [Online], 19 | 2021, Online since 15 September 2021, connection on 17 September 2021. URL: http:// journals.openedition.org/tourisme/3463 ; DOI: https://doi.org/10.4000/tourisme.3463

This text was automatically generated on 17 September 2021.

\section{cc)}

Mondes du tourisme est mis à disposition selon les termes de la licence Creative Commons Attribution - Pas d'Utilisation Commerciale - Pas de Modification 4.0 International. 


\title{
Mobility Justice and the Return of Tourism after the Pandemic
}

\author{
Justice mobilitaire et retour du tourisme après la pandémie
}

\author{
Mimi Sheller
}

\section{Introduction}

The collapse of travel demand due to the coronavirus pandemic-related closure of borders has severely disrupted tourism around the world. The impacts are especially severe for small islands and other tourism-dependent economies such as those in the Caribbean, Pacific, and Indian Ocean islands. This comes at a time of already existing concerns over climate change, over-tourism, pollution, and the general sustainability of existing modes of tourism. In these circumstances, how do we begin to imagine tourism's ethical futures? How should the return of tourism be handled and who will determine its futures? This would appear to be a compelling moment not simply to rebuild existing tourism-dependent economies, but to find new approaches to reduce the over-dependence on tourism, to mitigate the heavy carbon-footprint of tourism, as well as to repair the harmful effects of "overtourism" (Dodds, 2019; Dodds and Butler, 2019). Some tourism analysts call for us to "reconsider tourism's growth trajectory" and "accelerate the transformation of sustainable tourism" (Gössling et al., 2020, p. 13, 15). If there were ever a time to implement such a pivot in the global tourism economy, this would be it.

2 Unfortunately, however, the viral mobilities of Covid-19 unleashed not just a disruption of human mobilities, but also a vast intensification of existing uneven relations of (im)mobilities (Adey et al., 2021). As countries come out of the pandemic-related closure with different rates of recovery and vaccination, the uneven pressure on tourismdependent economies is especially acute, with a clear trade-off between opening up business again, and putting public health at risk. Many tourism-dependent states have attempted to mitigate these risks by imposing virus testing regimes, partial quarantines, or vaccination requirements. Others have tried to benefit by creating new 
"nomadic worker" visas to encourage longer-term visitor stays. And a few are trying to re-think the entire model of tourism and redirect their economies in more sustainable directions. Yet so far the challenges of deeply entrenched mobility injustices do not bode well for making a transition toward more ethical forms of tourism.

In this essay I want to argue that visions for recovery from the current and ongoing crises of tourism must reject mobility regimes that disempower the communities in which, and upon whom, tourism is visited. Kickstarting tourism cannot rely on sacrificing public health or natural ecosystems and protection of oceans, coasts, mangroves, and other flora and fauna. Servicing temporary visitors or nomadic workers is not a model for sustainable development. So-called "Island Innovation" and "Blue Ocean" economies cannot stand in for challenging the deep social injustices and harms to the natural world that are embedded in tourism development projects. Sustainable tourism is not simply an environmental project or a green business plan, but should be integrally linked to projects of mobility justice that help support the rebuilding of resilient regional ecologies and regenerative economies, rather than extractive economies and predatory tourism (Córdoba Azcárate, 2020).

In what follows, I will briefly introduce the concept of mobility justice in relation to practices of tourism. I then turn to the forms of pandemic (im)mobilities that have emerged and consider their relation to unsustainable tourism. I seek to show how the return of tourism after the pandemic has put us on a collision course with climate risk and ever more social injustice. It is urgent that we apply a mobility justice lens in order to avoid the worsening conditions that are coming.

\section{Mobility Justice and Tourism Inequities}

Building upon earlier concepts of "spatial justice" developed within critical geography, ${ }^{1}$ "mobility justice" (Sheller, 2018) is a concept for thinking across scales and fields of action that can help place everyday tourist practices and landscapes in relation to the production of wider uneven mobility infrastructures. The injustices of tourism's transnational mobility spaces are a function of the overarching regulatory and governance systems that some refer to as "mobility regimes". ${ }^{2}$ Glick Schiller and Salazar, for example, defined "regimes of mobility" as "the relationships between the privileged movements of some and the codependent but stigmatized and forbidden movement, migration, and interconnection between the poor, powerless, and exploited" (2013, p. 188). The concept of mobility justice allows us to better understand how the privilege of tourist mobilities reproduces forms of uneven power and inequality in the governance and control of movement. An approach grounded in mobility justice reveals how travel and tourism are constituted by mobility regimes that have deep historical roots in colonial relations, extractive economies, racial capitalism, and neocolonialism, and that continue to deeply impact climate injustice, social injustice and environmental injustice today.

6 Uneven powers of "motility" - meaning both the capability for movement and control over the movement of others - underwrite differential accessibility to various kinds of spaces, activities, and social goods. Motility can be defined as "the manner in which an individual or group appropriates the field of possibilities relative to movement and uses them", according to Kaufmann and Montulet (2008, p. 45). For example, who can be on a beach, who can enter a hotel lobby, or who can sell goods in particular places; 
who can have goods delivered to their home and who must work to deliver those goods; and who has access to grocery stores, healthcare, and clean, unpolluted environments, are all shaped by uneven motility. It is a question of the relation between mobilities and immobilities, and the circulation not only of people, but also of data, goods, services, waste and pollution. (Im)mobilities are not just the result of social inequalities, but are productive of those hierarchical systems through the performative differentiation of who can move, who can stay in a place, who can dwell, and who can cross borders each of which requires extended systems for the mobilities of data, objects and infrastructure. Tourism, through various kinds of enablement and disablement of access, is one of the key ways in which such hierarchies of differentiated motility are produced, maintained and experienced.

7 Different bodies (raced, classed, gendered, sexed, aged, nationally identified, and with differential bodily abilities) have very different degrees of access to and experiences of movement through the controlled geographies of air space and sea space, and in crossing borders and gaining access to ports of entry. Control of the transport corridors across land, sea, and air space are part of this production of differential (im)mobilities. Control of the air space, for example, includes entering personal data on a travel database, being able to purchase a ticket or get a visa for travel, physical passage through airports and security systems, being a passenger on an airplane, and having links to ground transportation upon arrival; for others, though, the experience of air space may involve waiting on the outskirts of the airport, working at the airport, driving other passengers to and from the airport, being a deportee whisked onto an airplane involuntarily, or watching planes fly overhead. Tourists enter these spaces as crucial actors and privileged participants in the making of uneven mobility regimes.

When we see thousands of migrants walking on foot, taking boats, swimming to cross borders, and paying human traffickers for dangerous modes of transport, we should recognize that this is because air space is not available for their movement and remains inaccessible to a majority of the world population. On one hand, the ease of mobility of international tourists normally relies on the fact that many millions of other people are unable to access air space, nor to travel in safety, security and comfort, nor to visit other places like the tourist. On the other hand, in the emergency situation of Covid-19, we also saw a sudden curtailment of tourist mobilities in favor of the mobility of "essential workers", revealing how both are the outcome of specific capitalist mobility regimes that produce mobility spaces and subjects. When business again needed travelers, we quickly began to see tourist arrivals allowed with simple PCR-test requirements for Covid-19 (which do not fully guarantee that they are not carrying the virus), and expecting service from workers in tourist destinations, who in many cases did not yet have access to Covid-19 vaccinations. In an illustration of mobility injustice, the virus spread in many such places that reopened for tourism but whose inhabitants were not sufficiently protected.

9 Additional mobility injustices occurred in relation to second home ownership and the use of Airbnb's during the pandemic. Around the world, the wealthy saw their incomes and investments grow during the pandemic, allowing them to purchase additional property often in vacation destinations. This led to myriad reports of well-off urbanites fleeing the pandemic, buying rural or remote properties, converting vacation homes, and turning them into remote live-work spaces, while keeping their urban jobs and incomes. This put great stress on these remote places to provide services and support 
for such populations with high "mobility capital", while local people were priced out of the market. ${ }^{3}$ When this involves islands and coastal areas, it has especially exacerbated the already existing privatization of coasts, huge price differentials in waterfront homes, and exclusion of local inhabitants from access to entire desirable "scenic" areas. The workers who service such properties must make ever longer journeys to get to work, and pay ever more of their income for housing given the dearth of affordable homes near such places. Service workers also put themselves at risk for exposure to the virus.

Echoing Lefebvre's "right to the city" and the questions of spatial justice already mentioned, Joseph Nevins has referred to travel as "the right to the world," but such travel is not available to all. Comparing the slowed mobility of undocumented migrants to those speeding through the official border crossing, he notes that "these distinct forms of mobility speak to an assertion by Eyal Weizman: 'To control a space you need to create differentiation in speed of movement'... Relatedly, you also need to create differentiation in resource and energy consumption" (Nevins, 2017, p. 29). The very systems that make travel easier, more speedy, and convenient for tourists are the same systems that slow travel for others - whether service workers, aspiring migrants, or those who have been displaced from their dwelling places in order to market land for tourism. Mobility regimes are built upon the control of space, speed, and energy, and tourists consume more of each than others. It is on this basis that I refer to all tourists as part of the "kinetic elite" (Sheller, 2018).

11 The privileged movement of tourists in post-disaster situations, including during the pandemic, needs to be located within these broader kinopolitical relations of im/ mobilities and differential speed, understood as unequal regimes of mobility. While the potential for movement and the capacity for movement are being increased for those who wish to travel as tourists, as time-share owners, or as overseas homeowners (as well as for external capital mobility and financial flows), both the potential and the capacity for movement are arguably being decreased for inhabitants of tourismdependent economies who find borders are closed, coasts are walled off, and their travel abroad is not welcome. As Caribbean and Pacific islands re-open tourist resorts, for example, arriving tourists are almost certainly bringing the virus into untouched populations as they circulate to hotels, restaurants, and bars and clubs (as seen recently in the new outbreak of Covid-19 in Bangkok, Thailand, for example, after night clubs were reopened). Tourism's uneven mobility regimes exacerbate the risks and vulnerabilities of unequal global (im)mobilities.

12 From this perspective, then, the answer is not simply to reopen tourist economies and bounce back to normal. Instead, we need to think carefully about what tourism should look like under conditions of greater mobility justice. Of course, these concerns were already there prior to the pandemic, and must be related to wider issues around climate change and sustainability. Alternative visions for post-pandemic tourism are needed both to avoid the reinforcement of already existing extractive and ecologically damaging forms of tourism, and to prepare for climate change adaptation and future survival in the face of ongoing climate-related disruptions, subsequent pandemics, as well as the ongoing tensions over rights to land, water, and unpolluted conditions of life, not to mention the rights of nature and non-human beings. 


\section{Pandemic (Im)mobilities and Unsustainable Tourism}

13 There is a large body of existing work on the relationship between tourism, sustainability, and resilience in small island contexts (e.g., Kelman, 2020; Mowforth and Munt, 2015; Mahon, Becken and Rennie, 2013), and on the wider environmental impacts of tourism (Gössling, 2002; Gössling and Hall, 2006; Gössling et al., 2016), which the pandemic has brought into even greater focus. The collapse of tourist travel brought about by the coronavirus pandemic adds a new complicating factor to consider. On the one hand, the sudden decrease in travel contributed to reduced air pollution, the disappearance of traffic, and the return of clear skies and quiet to many places that had been over-run with tourism. On the other hand, the precipitous drop in tourism earnings is having devastating effects on tourism-dependent economies. While many governments and business-owners are eager to re-start tourism and build back their service economies, some analysts argue that there is an urgent need to rebuild more sustainable economies and societies "beyond tourism" (Thompson, 2020), and there can be no getting "back to normal" under the circumstances (Gössling et al., 2020). What should tourism look like after the pandemic and in the face of ongoing climate crises?

There was already a longstanding critique of the problematic reliance on so-called "development" through tourism, which had many negative impacts on small islands especially. Campling, for example, argued that for "the genuine 'sustainable development' of SIDS [small island developing states], a popular democratic base of island citizens must exist within island societies that in turn cooperate and coordinateincluding material, political-social and operational linkages-across the spatially disparate regions of the global oceans" (Campling, 2006, p. 1). More recently, Cave and Dredge (2020, n.p.) point out that "Rising concerns about climate change, overtourism, declining employment and labour conditions and resource degradation have all highlighted the inadequacy of the current capitalist system in addressing the failures of mass tourism. Now, under COVID-19, there are calls for tourism to move beyond 'business as usual' and to find a pathway to regenerative tourism." Cave and Dredge argue that such regenerative tourism would embrace a "diverse economies framework" that "envisages the co-existence of capitalist, alternative capitalist and non-capitalist practices and provides a pathway to more resilient and regenerative tourism practices in tourism" (Cave and Dredge, 2020, n.p.).

Rebuilding tourism and transport infrastructure after natural disasters has often been one of the main "quick fix" recovery projects undertaken in islands and coastal areas that have been hit by environmental crises. We can consider the pandemic disruption to be like a natural disaster, and call for similar measures. However, there are numerous problems with tourism recovery in the current situation, echoing previous problems with tourism development more generally, but especially problems with post-disaster reconstruction. Through responses described as "disaster capitalism", wealthy investors often benefit from economic disruptions to make property investments and land grabs (Klein, 2018). These forms of extractive tourism are intensified by post-disaster rebuilding processes and raise key issues around "moral encounters in tourism" (Mostafanezhad and Hannam, 2016). A focus on mobility (in)justice and kinopolitics allows us to analyze some of the problematic economic, ecological, and ethical aspects of tourism recovery after the pandemic. 
In her book Stuck With Tourism, Matilde Córdoba Azcárate (2020) sensitively portrays how tourism geographies are not only predatory, but also how workers, regions, and nations get "stuck" with tourism as a developmental trap. She contributes the important new concepts of "tourism as predation" and of its attractive economic "stickiness as entrapment" $(2020$, p. 270$)$. Predatory extractive tourism describes some of the problematic structural effects of tourism development around the world, which, like other extractive enclaves such as mining, sacrifice life and places to the capture of resources for capitalist profit. Yet she also shows us why people working in the tourism sector, why regions such as Yucatan, and countries such as Mexico, still hold out hope for tourism to create a better future. The promise of tourism as a development strategy makes workers, government officials, planners, architects and designers, and of course real estate developers, all stick to its promise of improvement. Driven by the fear generated by the pandemic, the stickiness of tourism seems to be redoubled, driving us into its maul.

17 Tourism works in practice, Córdoba Azcárate argues, "by re-spatializing and scaling-up territory, nature, and sociocultural life for global consumption" (2020, p. 10). By this she means that "Governments and corporations engineer forests, mountains, beaches, deserts, islands, wetlands, and material infrastructures such as roads, streets, houses, hotels, pools, parks, or museums, designing them to shape new relations of people, capital, labor, and resources" (ibid., p. 10). People accept these "sacrificial logics" (ibid., p.18), risking the long-term sustainability of ecosystems and indigenous cultures, because they will generate jobs and keep tourists coming. Tourism promises the amelioration of precarious conditions of living, even as it takes away the conditions of possibility for life. That is its paradox: "acknowledging loss while willingly participating in predatory practices is what makes tourism geographies sticky" (ibid., p. 18). This includes the unintended consequences of ecotourism (Duffy, 2002, 2008; Córdoba Azcárate, 2020), and adapting to the predicted disruptions that ongoing climate change emergencies will bring to tourism (Reddy and Wilkes, 2012; Becken and Hay, 2007; Hall and Higham, 2005).

18 This is exactly what we see after the pandemic. Many governments, regions, and tourism promotion agencies are doubling down on the invitation of developers to bring tourism back, whatever the cost in public health risks or ecological damage. The predatory nature of tourism seems to have intensified, rather than been tamed by the pandemic. The sacrificial logics of such tourism hyper-development are exacerbating climate risks and moral jeopardy more than ever.

Tourism is not simply a casualty of climate change, moreover, it is a major contributor to its causes and its uneven harms (Becken and Hay, 2007). Tourism exacerbates the ongoing uneven geographies of climate vulnerability. The heavy fossil-fuel consumption associated with long-haul flights, the marine diesel consumed by megasized cruise ships, and the general use of vehicles, air-conditioning, electricity and energy-consuming buildings by tourists not only places a heavy burden on local infrastructure (especially of small islands and remote coastal areas), but also exacerbates the conditions of unequal exposure to climate change risks. Tourism also generates additional fossil fuel consumption related to the importation of food, goods and services, the disproportionate use of essential natural bodies such as water, plants and animals for food and excessive waste that cannot be processed locally, deeply damaging world-wide ecologies. The patterns of pandemic travel described above have 
also increased demand for private jet travel among those with high mobility capital, seeking safe, quick and convenient ways to get to their second homes or enjoy family trips again. Such private jet travel leads to especially high rates of consumption of per capita fossil fuel consumption.

Furthermore, tourist use of large internal-combustion vehicles, extensive air travel, and greater energy consumption exacerbates climate change, which in turn disrupts the lives of the lowest-income regions of the world who are least responsible for causing the climate crisis, leading to calls for the decarbonization of tourism (Hall, 2009; Hall and Higham, 2005). Recent critiques of "voluntourism" as a kind of niche tourism predicated upon "giving back" (Germann Molz, 2017; Mostafanezhad, 2014) show the ways that even humanitarian travel is implicated in capitalist development projects and forms of spatial rescaling associated with extractive economies (Córdoba Azcárate, 2020). The mobilities of the "kinetic elite" includes voluntourists, foreign humanitarians and even international academic researchers, like myself, who are able to stage humanitarian responses to disasters, while keeping disaster-affected populations contained at a distance (Sheller, 2020).

21 All these forms of tourism mobilities remake space, scale and power, as Córdoba Azcárate argues, and are thus implicated in reproducing uneven geographies and unsustainable tourism. We need to develop more critical perspectives on these phenomena if we are to come out of the pandemic-related travel disruption with better answers for tourism futures.

\section{Conclusion}

We cannot let the logics of disaster capitalism drive a race to the bottom, in which tourism is reopened with disregard for the human and ecological costs of precipitous kinetic elite mobilities alongside ever more restrictions and constraints on the mobilities of the workers within these service industries, not to mention those who simply want to dwell in their own homes without being displaced. We cannot continue to sacrifice coastal wetlands, mangrove forests, water sources, sand, coral reefs, and wildlife habitats in the futile hope that more hotel development, bigger cruise ship ports, or subdivisions of time-shares and second homes will bring back the tourists. Nor can we think that greenwashed tourism as spa retreat or nomadic work from a rainforest retreat will solve the problems of mobility injustice.

Mobility justice is a way to understand the deep flows of inequality and uneven accessibility in a world in which the mobile commons have been enclosed as private property and sold to the peripatetic traveler who can pay the price to visit. Mobility justice is a call for a new understanding of the politics of movement and a demand for justice for all in terms of how, when, and where we move or remain in places, without necessarily owning them as property. Mobility justice is an overarching concept for thinking about how power and inequality inform the governance and control of all forms of movement, including tourism. If there is a shift from "class struggle" to "place struggles," as Michel Lussault argues (Lussault, 2009), then we might also add to this a concept of kinopolitical struggles over place and mobility. The capacity to selfdetermine one's movements - what we might also call mobility sovereignty - is dependent on overcoming intersecting systems of oppression like racism, sexism, classism, and ableism, but also more generally on what I have theorized as overturning 
the high-carbon mobility regimes that privilege the kinetic elite who accumulate the highest mobility capital (Sheller, 2020).

While many people desire to travel the world, the period of pandemic confinement seems to have unleashed an intense demand for travel amongst those who feel cooped up. Certainly, there is also a strong economic pressure to bring back tourism-related jobs to highly tourism-dependent economies that have been decimated by the shutdown, especially small island states, the very ones ironically that are most vulnerable to the climate emergency and to pressures of over-tourism and pollution. Yet by thinking about the moral hazards and ethical complexities of uneven mobilities, I have argued, we can better assess the reopening of tourism economies with more thought to the harms they might bring. I hope this brief overview of some of the challenges of post-pandemic tourism can help policy-makers, practitioners, and travelers themselves reflect on what is gained and what is lost by returning to business as usual, or worse yet by implementing ever more extractive and predatory forms of tourism, which sacrifice the common good for the pleasure of the kinetic elite. It is time that we thought of tourism not simply as a profitable business opportunity, but also as a costly social and natural choice. In the face of the pandemic, as well as looming climate catastrophes, to care for the world may mean to travel less, and to travel the world may require us to be less careless.

Such an ethical practice of tourism might be built upon a "tourism commons" in which there are social rules for sharing and obligations for preservation of the commons ( $c$. Ostrom, 2010; and Barbagallo et al., 2019). The idea of "commoning mobility" has been advocated in recent studies of low-carbon mobility transitions to envision more "inclusive and collaboratively governed" cities. Anna Nikolaeva and collaborators ask how can we draw "on the logics of commoning such as communal decision-making practices, openness to new forms of perceiving the right to mobility as well as the right to immobility (the right not to be displaced), the awareness of the social production of mobility and the power relations inherent in it, as well as the commitment to creating equity and working in the interest of the public good"? (Nikolaeva et al., 2019, p. 353) Rather than simply limiting or ending tourism, therefore, can we imagine such a form of commoning tourism, that is committed to equity and the public good? As I have argued more generally, "A mobile commons is enacted within shared practices of movement, momentary gatherings, meeting and assembly, for a time, in a place, without owning it, so long as one does not ruin it, lay waste to it, degrade it, or take it away from the use of others" (Sheller, 2018, p. 169). This is the tourism I dream of for the future.

\section{BIBLIOGRAPHY}

Peter ADEY, Kevin HANNAM, Mimi SHELler and David TYFIELD, "Pandemic (Im)mobilities:

Introduction to the Pandemic (Im)Mobilities Special Issue”, Mobilities, vol. 16, n 1, p. 1-19, 2021

[https://doi.org/10.1080/17450101.2021.1872871]. 
Kafui Ablode Аттон, Rights in Transit: Public Transportation and the Right to the City in California's East Bay, University of Georgia Press, 2019.

Camille BARBAGALLO, Nicholas BEURET and David HARVIE (eds), Commoning with George Caffentzis and Silvia Federici, Pluto Press, 2019.

Susanne BECKEN and John E. HAY, Tourism and Climate Change: Risks and Opportunities, Channel View Publications, 2007.

Liam CAMPLING, "A Critical Political Economy of the Small Island Developing States Concept: South-South Cooperation for Island Citizens?", Journal of Developing Societies, vol. 22, $\mathrm{n}^{\circ} 3$, p. 235-285, 2006 [https://doi.org/10.1177/0169796X06068031].

Jenny CAVE and Diane DREDGE, "Regenerative Tourism Needs Diverse Economic Practices", Tourism Geographies, vol. 22, n 3, p. 1-11, 2020 [https://doi.org/10.1080/14616688.2020.1768434].

Giorgia CERIANI-SEBREGONDI, "Migrations internationales : vers un nouvel habiter ?", Travaux de l'Institut de géographie de Reims, vol. 29-30, n 115-118, p. 59-74, 2004.

Matilde CóRDOBA AZCÁRATE, Stuck with Tourism: Space, Power, and Labor in Contemporary Yucatan, University of California Press, 2020.

Rachel DoDDs (ed.), Overtourism: Issues, Realities and Solutions, De Gruyter, 2019.

Rachel DODDS and Richard W. BUTLER, Overtourism: Tourism at its Breaking Point, De Gruyter, 2019.

Rosaleen DUFFY, "Neoliberalising Nature: Global Networks and Ecotourism Development in Madagasgar", Journal of Sustainable Tourism, vol. 16, n 3, p. 327-344, 2008 [https://doi.org/ 10.2167/jost748.0].

Rosaleen DUFFY, A Trip Too Far: Ecotourism, Politics and Exploitation, Earthscan Publications Ltd, 2002. Jennie GERMANN MOLz, “Giving Back, Doing Good, Feeling Global: The Affective Flows of Family Voluntourism", Journal of Contemporary Ethnography, vol. 46, n 3, p. 334-360, 2017 [https:// doi.org/10.1177/0891241615610382].

Nina GLICK SCHILLER and Noel SALAZAR, "Regimes of Mobility Across the Globe", Journal of Ethnic and Migration Studies, vol. 39, n², p. 183-200, 2013.

Stefan GössLING, "Global Environmental Consequences of Tourism”, Global Environmental Change, vol. 12, n 4, p. 283-302, 2002 [https://doi.org/10.1016/S0959-3780(02)00044-4].

Stefan GöSSLING and C. Michael HALL (eds), Tourism and Global Environmental Change: Ecological, Economic, Social and Political Interrelationships, Routledge, 2006.

Stefan GösSLING, Amata RING, Larry DWYER, Ann-Christin ANDERSSON and C. Michael HALL, "Optimizing or Maximizing Growth? A Challenge for Sustainable Tourism", Journal of Sustainable Tourism, vol. 24, $\mathrm{n}^{\circ}$ 4, p. 527-548, 2016 [http://dx.doi.org/10.1080/09669582.2015.1085869].

Stefan GössLING, Daniel scoTT and C. Michael HALL, "Pandemics, Tourism and Global Change: A Rapid Assessment of COVID-19”, Journal of Sustainable Tourism, vol. 29, n 1, p. 1-20, 2021 [https:// doi.org/10.1080/09669582.2020.1758708].

C. Michael HALL, “Degrowing Tourism: Décroissance, Sustainable Consumption and Steady-State Tourism", Anatolia, vol. 20, n 1, p. 46-61, 2009 [https://doi.org/10.1080/13032917.2009.10518894].

C. Michael HALL and James HIGHAM (eds), Tourism, Recreation and Climate Change, Channel View Publications, 2005. 
Vincent KAUfMANN, Manfred Max BERGMAN and Dominique JOYE, "Motility: mobility as capital", International Journal of Urban and Regional Research, vol. 28, nº 4, p. 745-756, 2004.

Vincent KAUFMANN and Bertrand MONTULET, "Between Social and Spatial Mobilities: The Issue of Social Fluidity", in Weert Canzler, Vincent Kaufmann and Sven Kesselring (eds), Tracing Mobilities: Towards a Cosmopolitan Perspective, Ashgate, 2008.

Ilan KELMAN, "Islands of Vulnerability and Resilience: Manufactured Stereotypes?", Area, vol. 52, $\mathrm{n}^{\circ} 1$, p. 6-13, 2020 [https://doi.org/10.1111/area.12457].

Naomi KLEIN, The Battle for Paradise: Puerto Rico Takes on the Disaster Capitalists, Haymarket Books, 2018.

Rey коSLowsкI, “Global Mobility Regimes: A Conceptual Framework”, in Rey Koslowski (ed.), Global Mobility Regimes, Palgrave Macmillan, 2011, p. 1-25.

Henri LEFEBVRE, The Production of Space, Blackwell, 1991

Henri LEFEBVRE, Le Droit à la ville, S.l.: S.n., 1968.

Jacques LÉVY, Jean-Nicolas FAUCHILLE and Ana PóVOAS, Théorie de la justice spatiale, Odile Jacob, 2018.

Michel Lussault, De la lutte des classes à la lutte des places, Grasset, 2009.

Roché MAHON, Susanne BECKEN and Hamish RENNIE, Evaluating the Business Case for Investment in the Resilience of the Tourism Sector of Small Island Developing States. A Background Paper Contributing to the Global Assessment Report on Disaster Risk Reduction (GAR), LEaP Research Report No. 32, Lincoln University, 2013.

Mary MOSTAFANEZHAD, Volunteer Tourism: Popular Humanitarianism in Neoliberal Times, Ashgate Publishing, 2014.

Mary MOSTAFANEZHAD and Kevin HANNAM, Moral Encounters in Tourism, Routledge, 2016.

Martin MOWFORTH and Ian MUNT, Tourism and Sustainability: Development, Globalisation and New Tourism in the Third World, Routledge, 2015 ( $4^{\text {th }}$ ed.).

Elizabeth MURPHY-LEJEUNE, Student Mobility and Narrative in Europe: The New Strangers, Routledge, 2002.

Joseph NEVIns, “The Speed of Life and Death: Migrant Fatalities, Territorial Boundaries, and Energy Consumption", Mobilities, vol. 13, n 1, p. 29-44, 2017.

Anna nikolaeva, Peter Adey, Tim CResswell, Jane Yeonjae LeE, Andre nOVoA and Cristina TEMENos, "Commoning Mobility: Towards a New Politics of Mobility Transitions", Transactions of the Institute of British Geographers, $n^{\circ}$ 44, p. 346-360, 2019.

Elinor ostrom, "Beyond Markets and States: Polycentric Governance of Complex Economic Systems", American Economic Review, vol. 100, n³, p. 641-672, 2010.

Gordon. H. PIRIE, “On Spatial Justice”, Environment and Planning A, vol. 15, p. 465-473, 1983.

Maharaj Vijay REDDY and Keith wILKES, Tourism, Climate Change and Sustainability, Routledge, 2012. Ronen SHAMIR, “Without Borders? Notes on Globalization as a Mobility Regime”, Sociological Theory, vol. 23, n² 2, p. 197-217, 2005.

Mimi SHELLER, Island Futures: Caribbean Survival in the Anthropocene, Duke University Press, 2020.

Mimi SHELler, Mobility Justice: The Politics of Movement in an Age of Extremes, Verso, 2018. 
Mimi SHELLER, "From Spatial Turn to Mobilities Turn”, Current Sociology, vol. 65, n 4, p. 623-39, 2017.

Edward W. SOJA, Seeking Spatial Justice, University of Minnesota Press, 2010.

\section{NOTES}

1. For a discussion of the influence of Henri Lefebvre's The Production of Space (Blackwell, 1991) on mobilities theory, see Sheller, 2017; and for the origins of the concept of "spatial justice" see Soja, 2010; Lévy, Fauchille and Póvoas, 2018 ; and Pirie, 1983.

2. On the concept of mobility regimes see, e.g., Shamir, 2005; Koslowski, 2011; Glick Schiller and Salazar, 2013.

3. The concept of mobility capital builds on Pierre Bourdieu's theory of various kinds of "social capital" yet focuses specifically on access to mobility and accumulation of motility as a form of capital, also closely related to class distinction. See, e.g., Murphy-Lejeune, 2002; CerianiSebregondi, 2004; Kaufmann, Bergman and Joye, 2004.

4. Lefebvre, 1968; for an extension to mobility justice see also Attoh, 2019.

\section{ABSTRACTS}

The collapse of travel demand due to the coronavirus pandemic-related closure of borders has severely disrupted tourism around the world at a time of already existing concerns over climate change, over-tourism, pollution, and the general sustainability of existing modes of tourism. In these circumstances, this article addresses how we might begin to imagine tourism's ethical futures. This is a compelling moment to find new approaches to reduce the over-dependence on tourism, to mitigate the heavy carbon-footprint of tourism, as well as to repair the harmful effects of "over tourism". Yet the viral mobilities of Covid-19 have also unleashed a vast intensification of existing uneven relations of (im)mobilities. This article argues that sustainable tourism must be integrally linked to projects of mobility justice that help support the rebuilding of resilient regional ecologies and regenerative economies rather than extractive economies and predatory tourism.

L'effondrement de la demande de voyage dû à la fermeture des frontières liée à la pandémie de coronavirus a gravement perturbé le tourisme dans le monde entier, à un moment où l'on s'inquiétait déjà du changement climatique, du surtourisme, de la pollution et de la durabilité générale des modes de tourisme existants. Dans ces circonstances, cet article s'interroge sur la manière dont nous pourrions commencer à imaginer les futurs éthiques du tourisme. Le moment est venu de trouver de nouvelles approches pour réduire la dépendance excessive à l'égard du tourisme, pour atténuer sa lourde empreinte carbone et pour réparer les effets néfastes du «surtourisme». Pourtant, les mobilités virales de la Covid-19 ont également déclenché un accroissement important du caractère inégal des relations de(d') (im)mobilités existantes. Cet article soutient que le tourisme durable doit être intégralement lié à des projets de justice mobilitaire qui aident à soutenir la reconstruction d'écologies régionales résilientes et d'économies régénératives, plutôt que des économies extractives et un tourisme prédateur. 
INDEX

Mots-clés: tourisme éthique, justice mobilitaire, changement climatique, surtourisme, perturbation pandémique

Keywords: ethical tourism, mobility justice, climate change, over-tourism, pandemic disruption

\section{AUTHOR}

\section{MIMI SHELLER}

Dean of The Global School at Worcester Polytechnic Institute msheller[at]wpi.edu 